\title{
PENGEMBANGAN MODEL PEMBELAJARAN PENGUATAN VOCATIONAL LIFE SKILLS MAHASISWA BERWAWASAN KEWIRAUSAHAAN DI BIDANG TEKNIK MESIN
}

\author{
R. Mursid \\ Fakultas Teknik, Universitas Negeri Medan \\ mursid.tp@gmail.com
}

\begin{abstract}
Abstrak
Penelitian dan pengembangan ini bertujuan untuk: (1) mengembangkan model pembelajaran penguatan vocational life skills mahasiswa berwawasan kewirausahaan; dan (2) mengimplementasikan model pembelajaran penguatan vocational life skills mahasiswa berwawasan kewirausahaan. (3) mengetahui efektivitas dan keunggulan model; dan (4) mengimplentasikan model. Metode penelitian dan pengembangan dengan Borg \& Gall dan perencanaan strategi pembelajaran dalam pengembangan model dengan menggunakan rancangan Dick \& Carey. Berdasarkan hasil dari validasi ahli pada: ahli bidang studi, ahli desain pembelajaran, ahli desain grafis semuanya menunjukkan bahwa model pembelajaran penguatan vocational life skill layak digunakan dalam pelaksanaan pembelajaran pada mahasiswa jurusan teknik mesin. Juga pada uji coba perorangan, uji coba kelompok kecil dan uji coba lapangan menunjukan kelayakan model yang dikembangkan dan dalam kategori baik. Uji efektivitas, dapat disimpulkan bahwa nilai rata-rata hasil belajar yang diajar dengan menggunakan modul vocational life skills berwawasan kewirausahaan lebih tinggi dibandingkan dengan nilai rata-rata hasil belajar yang diajar dengan menggunakan buku teks.
\end{abstract}

Kata kunci: model pembelajaran penguatan vocational life skills, kewirausahaan, teknik mesin

\section{LEARNING MODEL DEVELOPMENT OF STUDENTS LIFE SKILLS VOCATIONAL STRENGTHENING INSIGHTFUL ENTREPRENEURSHIP IN MECHANICAL ENGINEERING}

\begin{abstract}
Research and development is aimed at: (1) develop learning models strengthening vocational life skills, entrepreneurial-minded students; and (2) implement a reinforcement learning model vocational life skills, entrepreneurial-minded students. (3) evaluate the efficacy and advantages of the model; and (4) implementing the models. Methods of research and development with Borg \& Gall and planning learning strategies in model development by using design Dick \& Carey. Based on the results of the validation experts at: expert studies, expert instructional design, graphic design expert everything suggests that the reinforcement learning model vocational decent life skill used in the implementation of learning in students majoring in mechanical engineering. Also on individual testing, small group trial and field trials showed the feasibility of the model developed and in both categories. Effectiveness test, it can be concluded that the average value of learning outcomes are taught using modules vocational life skills, entrepreneurial-minded higher than the average value of learning outcomes are taught using textbooks.
\end{abstract}

Keywords: reinforcement learning model vocational life skills, entrepreneurship, engineering 


\section{PENDAHULUAN}

Pendidikan kewirausahaan di Indonesia masih kurang memperoleh perhatian yang cukup memadai, baik oleh dunia pendidikan maupun masyarakat. Banyak pendidik yang kurang memperhatikan penumbuhan sikap dan perilaku kewirausahaan sasaran didik, baik di sekolah-sekolah baik tingkat menengah maupun perguruan tinggi, maupun di pendidikan profesional. Orientasi mereka, pada umumnya hanya pada menyiapkan tenaga kerja.

Permasalahan pengangguran maupakan masalah besar yang dihadapi bangsa Indonesia sekarang ini, beberapa tahun kedepan. Jumlah angkatan kerja di Sumatera Utara pada Agustus 2016 mencapai 6,36 juta orang atau bertambah sekitar 320 ribu orang bila dibanding angkatan kerja Agustus 2014, yaitu sebesar 6,27 juta orang. Sedangkan jumlah pengangguran terbuka mengalami peningkatan dari 391 ribu menjadi 421 ribu atau bertambah sebanyak 30 ribu orang. Tingkat Pengangguran Terbuka (TPT) mencapai 6,39 persen, mengalami peningkatan sebesar 0,16 poin dibanding TPT Agustus 2015, yaitu sebesar 6,23 persen. pekerja pada jenjang pendidikan Sarjana hanya sebesar 425 ribu orang $(6,88 \%)$ (Badan Pusat Statistik, 2016). Oleh karena itu Pendidikan Tinggi harus mampu bertindak, belajar dan mengembangkan kepribadian, jiwa wirausaha, berkeahlian khusus sesuai bidangnya agar dapat mempersiapkan lulusannya berperan aktif di masyarakat dalam menciptakan lapangan kerja atau menjadi tenaga professional.

Fenomena pengangguran lulusan perguruan tinggi yang setiap tahunnya terus meningkat tidak terlepas dari kondisi-kondisi sebagai berikut: (1) Masalah link and match antara lulusan perguruan tinggi dengan dunia kerja sampai sekarang ini belum terselesaikan dengan baik. Artinya lulusan perguruan tinggi masih dianggap kurang sesuai dengan kebutuhan dunia kerja, terutama oleh kalangan dudi. Menurut pandangan dudi lulusan perguruan tinggi kurang siap pakai, cukup lama menyesuaikan dengan lingkungan kerjanya (apabila sudah diterima sebagai pegawai) dan lebih bertindak sebagai pencari kerja (job seekers) ketimbang membuka lapangan (job creators) pekerjaan bagi orang lain. (2) Kondisi seperti tersebut di atas, sebenarnya seba- gai akibat dari orientasi kurikulum perguruan tinggi yang dominan pada IPK dan penyelesaian masa studi, sedangkan kompetensi lain misalnya bidang ketrampilan (life skills) atau kewirausahaan belum banyak dikembangkan. Pembinaan potensi mahasiswa selama di kampus lebih dominan mengembangkan aspek bakat dan minat dengan tujuan hanya untuk kepentingan mengisi waktu luang. Ada kecenderungan mahasiswa dalam kegiatan ekstra kampusnya lebih terfokus kepada hal-hal bidang politik ketimbang hal-hal bidang ekonomi atau kewirausahaan. Padahal setelah mahasiswa lulus umumnya mereka yang pertama kali dihadapi adalah dunia kerja yang selama mereka di kampus kurang mendapat perhatian.

Pembangunan kewirausahaan (entrepreneurship) sebaiknya ditumbuhkan untuk mendorong terciptanya suatu masyarakat sejahtera (prospirety). Penumbuhan yang efektif memerlukan sinergisitas diantara pelaku maupun stakeholder-nya, baik melalui regulasi, pendidikan maupun penyediaan fasilitas-fasilitas yang diperlukan untuk tumbuh kembangnya kewirausahaan. Pemerintah daerah berkewajiban mendorong lulusan PT agar menjadi wirausahawan kreatif yang mengolah kekayaan sumber daya alam: pertanian, perkebunan, dan perikanan yang berorientasi kepada nilai tambah sehingga mempunyai nilai ekonomis yang lebih tinggi. Cara tersebut akan memberi multiplier effect (efek pengganda) yang mampu menciptakan lapangan kerja dan pemasukan bagi pemerintah daerah. Kewirausahaan dapat diajarkan melalui pendidikan dan pelatihan. “... entrepreneurship has models, processes, and case studies that allow the topic to be studied and the knowledge to be acquired" (Kuratko \& Hodgetts, 2007, p. 34). Realita di lapangan, sistem pembelajaran saat ini belum sepenuhnya secara efektif membangun peserta didik memiliki akhlak mulia dan karakter bangsa termasuk karakter wirausaha.

Perguruan tinggi hendaknya mampu menjembatani antara perkembangan iptek dengan kebutuhan masyarakat di dunia nyata. Ditjen Dikti dapat mengadaptasi konsep Entrepreneurship Hidden Curriculum (EHC). Selanjutnya Ditjen Dikti memberi kewenangan kepada perguruan tinggi untuk menyusun dan menerapkan garis-garis besar rencana pembelajaran (GBRP) yang disesuaikan de- 
ngan peluang, kondisi masyarakat lokal perguruan tinggi berada, dan kemampuan perguruan tinggi tersebut. Dalam penerapan konsep EHC ini perguruan tinggi dapat bekerjasama dengan pemerintah provinsi, kabupatan dan atau kota. Entrepreneurship Hidden Curriculum $(E H C)$ diterapkan melalui pengintegrasian life skill dalam pengembangan pendidikan tinggi yang terdiri atas soft skill an hard skill kewirausahaan.

Hisrich \& Peters (Alma, 2002, p. 20) menyatakan bahwa entrepreneur is the process of creating something different with value by devoting the necessary time and effort, assuming the accompanying financial, psychological, and social risk and receiving the resulting rewards of monetary and personal satisfaction. Dengan bahasa yang sederhana dapat dikatakan bahwa entrepreneur atau wirausaha adalah merupakan proses menciptakan sesuatu yang berbeda dengan mengabdikan seluruh waktu dan tenaganya disertai dengan menanggung resiko keuangan, kejiwaan, sosial, dan menerima balas jasa dalam bentuk uang dan kepuasan pribadinya.

Pendidikan yang berbasis kewirausahaan adalah pendidikan yang menerapkan prinsip-prinsip dan metodologi ke arah internalisasi nilai-nilai pada peserta didiknya melalui kurikulum yang terintegrasi dengan perkembangan yang terjadi baik di lingkungan sekolah maupun lingkungan masyarakatnya serta penggunaan model dan strategi pembelajaran yang relefan dengan tujuan pembelajaranyan itu sendiri. Lembaga pendidikan tidak boleh hanya bertugas melahirkan banyaknya lulusan, akan tetapi yang jauh lebih penting adalah seberapa besar lulusanya itu dapat menolong dirinya sendiri dalam menghadapi tantangan di masyarakat atau dengan kata lain sekolah haruslah meningkatkan kecakapan hidup lulusannya (Anwar, 2004).

Kewirausahaan adalah suatu proses penerapan kreativitas dan inovasi dalam memecahkan persoalan dan menemukan peluang untuk memperbaiki kehidupan. Kewirausahaan adalah segala hal yang berkaitan dengan sikap, tindakan, dan proses yang dilakukan oleh para entrepreneur dalam merintis, menjalankan dan mengembangkan usaha mereka (Nasution \& Suef, 2007, p. 4). Esensi dari kewirausahaan adalah menciptakan nilai tambah di pasar melalui proses pengkombinasian sumber daya dengan cara-cara baru dan berbeda agar dapat bersaing.

Pengembangan budaya kewirausahaan di perguruan tinggi bertujuan: (1) menumbuhkembangkan budaya kewirausahaan di dalam lingkungan perguruan tinggi untuk mendorong terciptanya wirausahawan baru, (2) mendorong pemanfaatan hasil penelitian dan pengembangan menjadi perangkat yang dapat digunakan masyarakat dan bernilai komersial, (3) mewujudkan sinergi potensi perguruan tinggi dengan potensi industri/usaha kecil menengah sehingga dapat menumbuhkembangkan industri-industri kecil dan menengah yang mandiri, (4) meningkatkan peluang keberhasilan wirausaha baru melalui kegiatan pelayanan konsultasi terpadu. Mendorong akselerasi pemulihan ekonomi (economy recovery) Indonesia melalui penanggulangan kemiskinan dan penyediaan lapangan kerja dengan tumbuhnya wirausaha baru yang kuat, baik dari segi kualitas barang produksi dan jasa maupun dari pemasarannya, (5) menumbuhkembangkan kegiatan-kegiatan yang mendorong terwujudnya income generating unit di perguruan tinggi Indonesia dalam mengantisipasi diberlakukannya otonomi perguruan tinggi. Oleh karena itu menurut Potter (2008, p. 182), Key role of entrepreneurial education is to create momentum for change; development starts in small steps, as others follow and momentum grows. Pendapat tersebut dapat dimaknai bahwa pendidikan kewirausahaan dimanfaatkan sebagai momentum awal menciptakan lulusan yang berjiwa wirausaha melalui pembentukan pola pikir (mindset) dan jiwa (spirit) menjadi pengusaha.

Seels \& Richey (1994) mengatakan bahwa strategi pembelajaran adalah spesifikasi untuk memilih dan mendosentkan proses dan kegiatan-kegiatan dalam suatu pelajaran. Sementara itu, Dick \& Carey (1985), mengatakan bahwa strategi pembelajaran menjelaskan komponen-komponen umum dari suatu set bahan instruksional dan prosedur-prosedur yang akan digunakan bersama bahan-bahan tersebut untuk menghasilkan hasil belajar tertentu pada mahasiswa. Menurutnya, ada lima komponen umum dari strategi instruksional yakni: kegiatan pra-instruksional, penyajian informasi, partisipasi mahasiswa, tes dan tindak lanjut. 
Menurut Dick, Carey, \& Carey (2005), strategi pembelajaran biasanya menjelaskan komponen umum dari satu set materi dan prosedur pembelajaran yang akan digunakan dengan bahan bahan lain untuk menghasilkan hasil belajar tertentu dari pihak mahasiswa. Selanjutnya, Dick \& Carey (1985) juga merinci lima komponen strategi pembelajaran yakni: (1) kegiatan pra instruksional, (2) penyajian informasi, (3) partisipasi mahasiswa, (4) tes, dan (5) tindak lanjut. Gagne, Briggs dan Wager, mengatakan bahwa strategi pembelajaran adalah suatu rencana untuk membantu mahasiswa dengan usaha belajarnya untuk setiap tujuan yang ada. Ini dapat mengambil bentuk rencana pembelajaran, atau satu set spesifikasi produksi untuk bahan yang disajikan dengan media. Tujuan mengembangkan strategi sebelum pengembangan bahan pembelajaran adalah untuk menggarisbawahi bagaimana kegiatan pembelajaran akan terkait dengan pencapaian tujuan pembelajaran.

Miarso (2005) mendefinisikan strategi pembelajaran sebagai pendekatan menyeluruh dalam pembelajaran yang berupa pedoman umum dan kerangka kegiatan yang dijabarkan dari pandangan falsafat atau teori mengenai belajar dalam kondisi tertentu dan yang ditetapkan untuk mencapai tujuan umum. Strategi pembelajaran yang dimaksud dalam penelitian ini adalah perencanaan sistematis dan terpadu yang mencakup urutan kegiatan pembelajaran, metode, media dan alokasi waktu yang ditetapkan sebelum pembelajaran untuk mencapai tujuan pembelajaran.

Tujuan pendidikan keterampilan hidup (life skills) menurut Kementerian Pendidikan Nasional (2002), adalah untuk meningkatkan pengetahuan, keterampilan, dan sikap yang dibutuhkan memasuki dunia kerja baik bekerja mandiri atau bekerja pada suatu perusahaan produksi jasa, sesuai bakat dan minatnya untuk mendatangkan penghasilan yang layak untuk memenuhi kebutuhan hidupnya. Peserta didik harus dapat memiliki personal skill, thinking skill, socials skill, academic skill, dan vocational skill. Vocational life skill adalah kecakapan kejuruan yang terkait dengan bidang pekerjaan tertentu. Inilah yang perlu diberi penguatan. Life skills mendekatkan lulusan dengan dunia nyata dan membekali peserta didik agar mampu mencari alternatif pemecahan untuk mengatasi permasalahan hidup tanpa tertekan. Di samping itu, lulusan pandai memanfaatkan peluang untuk mengatasi pengangguran dan mampu bekerja sambil belajar.

Materi yang relevan dalam pengembangan model pembelajaran jiwa kewirausahaan, meliputi; (1) mengidentifikasi sikap dan prilaku wirausaha, (2) menerapkan sikap dan prilaku kerja prestatif (selalu ingin maju), (3) merumuskan solusi masalah, (4) mengembangkan semangat wirausaha (inovatif, kreatif, motivasi, sikap bekerja efektif dan efisien), (5) membangun komitmen bagi dirinya dan orang lain (menerapkan perilaku tepat waktu, menerapkan perilaku tepat janji, menerapkan kepedulian terhadap mutu hasil kerja, menerapkan komitmen tinggi terhadap pengendalian mutu), (6) mengambil risiko usaha, (7) membuat keputusan, (8) menunjukkan sikap pantang menyerah dan ulet (melakukan sikap pantang menyerah dan ulet dalam kegiatan usaha), (9) mengelola konflik, (10) membangun visi dan misi usaha, (11) menganalisis peluang usaha (mengembangkan ide dan peluang usaha), (12) menganalisis aspek-aspek perencanaan usaha, (13) menyusun proposal usaha, (14) mempersiapkan pendirian usaha, (15) menghitung risiko menjalankan usaha, (16) menjalankan usaha kecil, dan (17) mengevaluasi hasil usaha.

Pengembangan model pembelajaran yang baik disesuaikan dengan kondisi tertentu. Kondisi ini adalah besar kecil atau kompleks tidaknya suatu lembaga pendidikan, ruang lingkup tugas lembaga pendidikan, serta kemampuan pengelola. Joyce, Weil, \& Beverly (1996) menjelaskan model pembelajaran adalah suatu perencanaan yang digunakan sebagai pedoman dalam merencanakan pembelajaran di kelas untuk menentukan perangkat-perangkat pembelajaran serta mengarahkan kita dalam mendisain pembelajaran untuk membantu pebelajar sedemikian hingga tujuan pembelajaran tercapai. Dengan demikian pada hakekatnya model pembelajaran merupakan pola langkah yang meliputi analisis, pengembangan, dan pembuatan materi, dan evaluasi hasil pembelajaran dalam rangka memberikan kemudahan mahasiswa untuk mencapai hasil belajar.

Model pembelajaran menurut Mager \& Beach (1967) bahwa proses pembelajaran memerlukan tiga tahap: (1) tahap persiapan (preparation phase); (2) tahap pengembangan (development phase); dan (3) tahap perbaik- 
an/kemajuan (improvement phase). Tahap persiapan direncanakan untuk memberikan jaminan bahwa informasi dan praktek yang penting untuk suatu pekerjaan tertentu benarbenar termasuk dalam pembelajaran. Pertama melakukan analisis pekerjaan, berikutnya analisis tugas, membuat tujuan pembelajaran, dan menguji. Tahap pengembangan melalui unit outlining yaitu tugas kerja agar supaya pada akhir unit peserta dapat melakukan sesuatu yang sebelumnya ia tidak dapat lakukan, sequencing, content selection, procedures selection, sequencing and lesson plan completion, dan course tryout.

Gunter, Estes, \& Schwab (1990) mendefinisikan an instructional model is a stepby-step procedure that leads to specific learning outcomes. Joyce \& Weil (2000) mendefinisikan model pembelajaran sebagai kerangka konseptual yang digunakan sebagai pedoman dalam melakukan pembelajaran. Dengan demikian, model pembelajaran merupakan kerangka konseptual yang melukiskan prosedur yang sistematis dalam mengorganisasikan pengalaman belajar untuk mencapai tujuan belajar.

Selain memperhatikan rasional teoretik, tujuan, dan hasil yang ingin dicapai, model pembelajaran memiliki lima unsur dasar Joyce \& Weil (2000), yaitu; (1) syntax, yaitu langkah-langkah operasional pembelajaran; (2) social system, adalah suasana dan norma yang berlaku dalam pembelajaran; (3) principles of reaction, menggambarkan bagaimana seharusnya dosen memandang, memperlakukan, dan merespon mahasiswa; (4) support system, segala sarana, bahan, alat, atau lingkungan belajar yang mendukung pembelajaran; dan (5) instructional dan nurturant effects hasil belajar yang diperoleh langsung berdasarkan tujuan yang disasar (instructional effects) dan hasil belajar di luar yang disasar (nurturant effects).

Kaitannya dengan pengembangan model pembelajaran berfungsi mengarahkan kita untuk mendesain pembelajaran yang digunakan sebagai pedoman dalam penyelenggaraan pembelajaran agar tercapai pembelajaran yang efektif, efisien, berdaya tarik, dan humanis.Joyce et al. (1996) menjelaskan model pembelajaran adalah suatu perencanaan atau suatu pola yang digunakan sebagai pedoman dalam merencanakan pembelajaran di kelas atau pembelajaran dalam tutorial dan untuk menentukan perangkat perangkat pembelajaran serta mengarahkan kita dalam mendesain pembelajaran untuk membantu pebelajar sedemikian hingga tujuan pembelajaran tercapai.

Pengembangan model pembelajaran penguatan vocational life skills berwawasan kewirausahaan didasarkan pada hasil analisis situasi, analisis permasalahan dan kebutuhan mahasiswa untuk berwirausaha. Ada sembilan Mata kuliah keahlian dan satu Mata kuliah kewirausahaan pada tiap bidang studi yang masuk dalam rancangan penguatan sesuai minat/motivasi mahasiswa dan diarahkan pada jenis usaha yang dipilih mahasiswa.

\section{METODE PENELITIAN}

Penelitian ini menggunakan model penelitian dan pengembangan (Research and development). Penelitian dan pengembangan oleh Borg \& Gall (1989) menyatakan bahwa prosedur penelitian pengembangan pada dasarnya terdiri dari dua tujuan utama, yaitu: (1) mengembangkan produk, dan (2) menguji keefektifan produk dalam mencapai tujuan. Tujuan pertama disebut sebagai fungsi pengembangan sedangkan tujuan kedua disebut sebagai validasi. Dengan demikian konsep penelitian pengembangan lebih tepat diartikan sebagai upaya pengembangan yang sekaligus disertai dengan upaya validasinya. Mata $\mathrm{ku}-$ liah Teknik Mesin yang dipilih adalah Teknologi Pengelasan, Teknologi Pembentukan, Teknologi Pemesinan, dan Kewirausahaan. Dalam penelitian ini tidak menggunakan populasi secara umum, tetapi terbatas untuk menggali kedalaman fenomena.

Perencanaan strategi pembelajaran dalam pengembangan model menggunakan rancangan Dick \& Carey (1985), Dick \& Carey (1996) dan Dick et al. (2005) dengan mengacu pada sepuluh tahapan pengembangan. Untuk mengetahui efektivitas model pembelajaran yang dikembangkan dilakukan pendekatan eksperimen penelitian dengan quasi eksperiment dengan rancangan control group post test only.

Penelitian dilakukan di Jurusan Teknik Mesin Fakultas Teknik Universitas Negeri Medan. Baik uji coba perorangan, ujicoba kelompok kecil, dan ujicoba utama dilakukan di Unimed. Subjek penelitian adalah mahasiswa dan dosen. Pada tahap pengembangan model 
pembelajaran vocational life skills berwawasan kewirausahaan, penentuan sasaran dalam hal ini adalah dosen, pakar pembelajaran, ahli bidang studi, dan mahasiswa yang menilai model pembelajaran yang telah dikembangkan berdasarkan kriteria, sebagai berikut: (1) evaluasi pakar pembelajaran (expert judgement) ditentukan berdasarkan kepakaran yang dimilikinya, (2) evaluator yang melaksanakan evaluasi ditentukan berdasarkan pada kemampuan dosen dengan klasifikasi ahli bidang studi.

Prosedur pengembangan mengikuti atau mengacu pada langkah-langkah yang dikembangkan oleh Borg \& Gall (1989); (1) melakukan penelitian pendahuluan dan pengumpulan informasi, (2) melakukan perencanaan (3) mengembangkan produk awal, (4) melakukan uji coba permulaan, (5) melakukan revisi terhadap produk utama, (6) melakukan uji lapangan utama, (7) melakukan revisi terhadap produk operasional, (8) melakukan uji lapangan operasional, (9) melakukan revisi terhadap produk akhir (10) mendesiminasikan dan mengimplementasikan produk. Namun karena keterbatasan yang ada dalam penelitian ini tidak dilakukan langkah desiminasi dan implementasi produk.

Analisis data dalam penelitian dan pengembangan ini menggunakan analisis deskriptif kuantitatif. Semua data yang terkumpul dianalisis dengan teknik statistik deskriptif yang secara kuantitatif dipisahkan menurut kategori untuk mempertajam penilaian dalam menarik kesimpulan. Analisis data dalam penelitian dan pengembangan ini dijelaskan dalam tiga, yaitu tahap studi pendahuluan, pengembangan dan validasi.

Pada tahap pengembangan beberapa pendekatan analisis yang digunakan yaitu: (a) pelaksanaan dan hasil pengembangan desain model, dideskripsikan dalam bentuk sajian data, kemudian dianalisis secara kualitatif, (b) pada ujicoba terbatas, hasil ujicoba penerapan desain model dianalisis dengan pendekatan kuantitaif, (c) pada ujicoba lebih luas, di samping menggunakan pendekatan analisis deskriptif kualitatif, juga digunakan analisis statistik (kuantitatif), dengan formula statistik uji-t (t-test) untuk mengukur hasil penerapan desain model pada kondisi sebelum (pra) dan sesudah (pasca) penerapan. Pada tahap validasi, keberartian dan efektivitas hasil penerapan model dianalisis menggunakan pendekatan kuantitatif (quasi exsperimental), dengan membandingkan hasil pada kelompok (subjek penelitian) eksperimen dan kelompok kontrol, pada kondisi sebelum dengan sesudah penerapan.

\section{HASIL DAN PEMBAHASAN}

\section{Hasil}

Berdasarkan data hasil studi pendahuluan melalui penyebaran instrumen persepsi dosen dalam penyelenggaraan pembelajaran, masing-masing ditunjukkan pada Tabel 1.

Tabel 1. Persepsi Dosen dalam Proses Pembelajaran Penguatan Vocational Life Skills Berwawasan Kewirausahaan

\begin{tabular}{lc}
\hline \multicolumn{1}{c}{$\begin{array}{c}\text { Penyelenggaraan Pembelajaran Penguatan Vocational Life Skills } \\
\text { Berwawasan Kewirausahaan }\end{array}$} & $\begin{array}{c}\text { Persentase } \\
\text { Keberhasilan }\end{array}$ \\
\hline 1. Mengorganisasian pembelajaran Penguatan Vocational Life Skills & 85,54 \\
Berwawasan Kewirausahaan & \\
2. Komunikasi secara efektif dalam pembelajaran Penguatan Vocational & 83,50 \\
$\quad$ Life Skills Berwawasan Kewirausahaan & \\
3. Penguasaan dan antusiasme dalam pembelajaran Penguatan Vocational & 83,75 \\
$\quad$ Life Skills Berwawasan Kewirausahaan & 81,50 \\
4. Sikap positif terhadap mahasiswa dalam pembelajaran Penguatan & \\
Vocational Life Skills Berwawasan Kewirausahaan & 83,75 \\
5. Pemberian umpan balik/balikan dan penilaian & 79,25 \\
6. Strategi/pendekatan pembelajaran Penguatan Vocational Life Skills & \\
Berwawasan Kewirausahaan & 83,44 \\
7. Hasil belajar mahasiswa & 83,75 \\
8. Sarana dan prasarana, fasilitas pendukung dan lingkungan belajar & 82,83 \\
Studi Pendahuluan Pada Analisis Kebutuhan & \\
\hline
\end{tabular}


Tabel 2. Persepsi Mahasiswa dalam Penyelenggaraan Pembelajaran

\begin{tabular}{|c|c|}
\hline $\begin{array}{l}\text { Penyelenggaraan Pembelajaran Penguatan Vocational Life Skills Berwawasan } \\
\text { Kewirausahaan }\end{array}$ & $\begin{array}{c}\text { Persentase } \\
\text { Keberhasilan }\end{array}$ \\
\hline $\begin{array}{l}\text { 1. Mengorganisasian pembelajaran Penguatan Vocational Life Skills } \\
\text { Berwawasan Kewirausahaan }\end{array}$ & 82,96 \\
\hline $\begin{array}{l}\text { 2. Komunikasi secara efektif dalam pembelajaran Penguatan Vocational } \\
\text { Life Skills Berwawasan Kewirausahaan }\end{array}$ & 82,75 \\
\hline $\begin{array}{l}\text { 3. Penguasaan dan antusiasme dalam pembelajaran Penguatan Vocational } \\
\text { Life Skills Berwawasan Kewirausahaan }\end{array}$ & 82,78 \\
\hline $\begin{array}{l}\text { 4. Sikap positif terhadap mahasiswa dalam pembelajaran Penguatan } \\
\text { Vocational Life Skills Berwawasan Kewirausahaan }\end{array}$ & 82,50 \\
\hline 5. Pemberian umpan balik/balikan dan penilaian & 81,04 \\
\hline $\begin{array}{l}\text { 6. Strategi/pendekatan pembelajaran Penguatan Vocational Life Skills } \\
\text { berwawasan Kewirausahaan }\end{array}$ & 76,04 \\
\hline 7. Hasil belajar mahasiswa & 80,94 \\
\hline Studi Pendahuluan Pada Analisis Kebutuhan & 81,17 \\
\hline
\end{tabular}

\begin{tabular}{|c|c|c|c|}
\hline & PERENCANAAN & PELAKSANAAN & EVALUASI \\
\hline $\begin{array}{l}\text { INTERNAL: } \\
\text { - Kurikulum KKNI } \\
\text { Kompetensi } \\
\text { - Capaian } \\
\text { pembelajaran } \\
\text { - Kondisi/masalah } \\
\text { belajar } \\
\text { Mahasiswa } \\
\text { - Mata kuliah } \\
\text { kewirausahaan } \\
\text { - Motivasi } \\
\text { /Dorongan } \\
\text { - Studi Pustaka } \\
\text { - Sarana/Pra } \\
\text { Sarana Fasilitas } \\
\text { Belajar }\end{array}$ & $\begin{array}{l}\text { 1. Merumuskan Tujuan } \\
\text { kompetensi } \\
\text { 2. Menganalisis kendala } \\
\text { dan karakteristik bidang } \\
\text { studi } \\
\text { 3. Menyusun silabus, RPS, } \\
\text { dan Kontrak Perkuliahan } \\
\text { 4. Menganalisis } \\
\text { Karakteristik Mahasiswa } \\
\text { 5. Merumuskan strategi } \\
\text { pembelajaran vocational } \\
\text { life skills berwawasan } \\
\text { kewirausaha } \\
\text { 6. Membuat modul dan } \\
\text { lembar kerja dan tugas } \\
\text { 7. Merancang kebutuhan } \\
\text { waktu dan sumber belajar } \\
\text { 8. Menyusun tugas: tugas } \\
\text { rutin, rekayasa ide, } \\
\text { project. } \\
\text { 9. Menyusun alat evaluasi, } \\
\text { autentik assessment } \\
\text { melalui: Edukatif, } \\
\text { Autentik, objektif, } \\
\text { akuntabel, dan } \\
\text { transparan assessment } \\
\text { 10. Mengidentifikasi masalah } \\
\text { untuk pengembangan } \\
\text { wirausaha }\end{array}$ & $\begin{array}{l}\text { Strategi Pembelajaran: } \\
\text { 1. Active learning } \\
\text { 2. Constructive } \\
\text { 3. Collaborative } \\
\text { 4. Membangun sikap kreatif, } \\
\text { inovatif, dan produktif } \\
\text { 5. Meningkatkan spirit } \\
\text { kewirausahaan } \\
\text { 6. Meningkatkan } \\
\text { keterampilan dan } \\
\text { pengelolaan usaha } \\
\text { berwirausaha } \\
\text { 7. Melakukan } \\
\text { pendampingan } \\
\text { pengembangan usaha, } \\
\text { modal dan peralatan } \\
\text { 8. Mempraktekkan } \\
\text { kewirausahaan } \\
\text { pengembangan jaringan } \\
\text { usaha dan akses sesuai } \\
\text { kebutuhan }\end{array}$ & $\begin{array}{l}\text { 1. Tes Formatif } \\
\text { dan Sumatif } \\
\text { 2. Pendekatan } \\
\text { PAN/PAP } \\
\text { 3. Pendekatan } \\
\text { Afektif, Kognitif } \\
\text { dan } \\
\text { Psikomotorik } \\
\text { 4. Tugas rutin } \\
\text { 5. Critical books } \\
\text { review } \\
\text { 6. Critical Jaournal } \\
\text { review } \\
\text { 7. Rekayasa ide } \\
\text { kewirausahaan } \\
\text { 8. Mini research } \\
\text { 9. Project berbasis } \\
\text { kewirausahaan } \\
\text { 10. Wirausaha } \\
\text { baru/rintisan } \\
\text { usaha jasa } \\
\text { maupun produk } \\
\text { 11. Portopolio }\end{array}$ \\
\hline
\end{tabular}

Gambar 1. Model Pembelajaran Penguatan Vokasional life skill berwawasan Kewirausahaan 
Berdasarkan data hasil studi pendahuluan melalui penyebaran instrumen persepsi mahasiswa dalam penyelenggaraan pembelajaran, masing-masing ditunjukkan pada Tabel 2.

Pengembangan desain model dalam penelitian ini difokuskan pada desain model Pembelajaran penguatan vocational life skills berwawasan kewirausahaan. Untuk memperoleh peningkatan prestasi belajar mahasiswa dalam aspek kompetensi yang sesuai dengan standar kompetensi dan kompetensi dasar, maka pembelajaran kewirausahaan berbasis kompetensi dikembangakan dalam tiga aspek yang terintegrasi, yaitu; (1) pengembangan desain perencanaan model; (2) pengembangan desain pelaksanaan model; dan (3) pengembangan desain evaluasi model.

Berdasarkan data hasil observasi yang dilakukan terhadap pelaksanaan pembelajaran dosen dalam uji coba terbatas tahap I dan tahap II, masing-masing ditunjukkan dalam Tabel 3, 4, 5, dan 6 .

Tabel 3. Keterterapan Pelaksanaan Pembelajaran pada Uji Coba Terbatas

\begin{tabular}{lc}
\hline \multicolumn{1}{c}{ Keterterapan Pelaksanaan Pembelajaran } & Persentase Keberhasilan \\
\hline I Pra Pembelajaran Kewirausahaan & 68,06 \\
II. Kegiatan Inti Pembelajaran: & \\
A. Penguasaan materi pembelajaran & 73,21 \\
B. Pendekatan/Strategi pembelajaran & 75,69 \\
C. Pemanfaatan sumber/media pembelajaran & 58,33 \\
D. Pembelajaran yang memicu keterlibatan mahasiswa & 80,00 \\
E. Penilaian proses dan hasil belajar & 56,25 \\
F. Penggunaan bahasa & 87,50 \\
G. Penutup & 56,25 \\
\hline
\end{tabular}

Tabel 4. Penilaian Mahasiswa terhadap Pelaksanaan Pembelajaran dengan Menggunakan Model Pembelajaran Penguatan Vocational Life Skills Berwawasan Kewirausahaan pada Uji Coba Terbatas

\begin{tabular}{lc}
\hline \multicolumn{1}{c}{ Kriteria Penilaian terhadap Penerapan Pelaksanaan Model Pembelajaran } & $\begin{array}{c}\text { Persentase } \\
\text { Keberhasilan }\end{array}$ \\
\hline $\begin{array}{l}\text { A. Mudah dipahami dan dimengerti dalam pelaksanaan pembelajaran dengan } \\
\text { menggunakan model pembelajaran penguatan vocational life skills berwawasan } \\
\text { kewirausahaan yang dikembangkan bagi mahasiswa }\end{array}$ & 77,68 \\
$\begin{array}{l}\text { B. Menyenangkan, membuat bersemangat bekerja dan belajar, berkeinginan untuk } \\
\text { berkembang, menjadi akrab, dan dapat melakukan kerja sama dengan baik bagi } \\
\text { mahasiswa bila meggunakan model pembelajaran penguatan vocational life skills } \\
\text { berwawasan kewirausahaan. }\end{array}$ & 78,13 \\
$\begin{array}{l}\text { C. Meningkatkan dalam belajar dan bekerja, dan meningkatkan kompetensi } \\
\text { mahasiswa bila menggunakan model pembelajaran penguatan vocational life skills } \\
\text { berwawasan kewirausahaan }\end{array}$ & 76,96 \\
$\begin{array}{l}\text { Rata-rata penilaian mahasiswa terhadap penerapan model pembelajaran penguatan } \\
\text { vocational life skills berwawasan kewirausahaan }\end{array}$ & 77,50 \\
\hline
\end{tabular}

Tabel 5. Data Hasil Kompetensi Uji Coba Terbatas

\begin{tabular}{llc}
\hline Tugas & Aspek Penilaian & Persentase Keberhasilan \\
\hline \multirow{2}{*}{ A } & 1. Memperhatikan tindakan keselamatan kerja & 51,19 \\
2. Menentukan persyaratan kerja & 62,50 \\
& 3. Melakukan wirausaha & 51,88 \\
4. Memeriksa komponen untuk kesesuaian dalam berwirausaha & 61,43 \\
\hline \multirow{2}{*}{ 1. Memperhatikan tindakan keselamatan kerja } & 61,90 \\
2. Menentukan persyaratan kerja & 72,32 \\
& 3. Melakukan wirausaha & 64,29 \\
& 4. Memeriksa komponen untuk kesesuaian dalam berwirausaha & 65,98 \\
\hline
\end{tabular}


Tabel 6. Data Hasil Kompetensi wirausaha

\begin{tabular}{cc}
\hline Tugas dan Kompetensi Kewirausahaan & Persentase Keberhasilan \\
\hline A :Penilaian pada: Metode pengerjaan, Hasil Keterampilan Kewirausahaan & 66,93 \\
B: Penilaian pada: Metode pengerjaan, Hasil Keterampilan Kewirausahaan & 67,86 \\
\hline
\end{tabular}

\section{Pengajuan Persyaratan Analisis}

\section{Uji Normalitas Data}

Uji normalitas dilakukan untuk mencari kenormalan dari sampel yang diteliti. Uji normalitas menggunakan rumus uji liliefors. Setelah dilakukan perhitungan, diperoleh nilai $\mathrm{L}_{\text {hitung }}$ untuk kelas yang menggunakan model pembelajaran penguatan vocational life skills berwawasan kewirausahaan dengan perangkat modul adalah 0,074 pada taraf $\alpha=0,05$ de$\operatorname{ngan} \mathrm{n}=35$. $\mathrm{L}_{\text {tabel }}$ adalah 0,15 . Hal ini menunjukkan $\mathrm{L}_{\text {hitung }}<\mathrm{L}_{\text {tabel }}$, artinya sampel berasal dari populasi yang berdistribusi normal.

Sedangkan uji normalitas nilai pretes untuk kelas konvensional yang menggunakan buku teks diperoleh nilai $\mathrm{L}_{\text {hitung }}=0,067$, dan $\mathrm{L}_{\text {tabel }}$ adalah 0,15 pada taraf $\alpha=0,05$ dengan $\mathrm{n}$ $=35$. Hal ini menunjukkan $\mathrm{L}_{\text {hitung }}<\mathrm{L}_{\text {tabel}}$, artinya sampel berasal dari populasi yang berdistribusi normal.

Setelah dilakukan perhitungan, maka pada kelas yang menggunakan modul vocational life skills berwawasan kewirausahaan diperoleh nilai $\mathrm{L}_{\text {hitung }}=0,089, \mathrm{~L}_{\text {tabel }}$ pada taraf $\alpha=0,05$ dengan $n=35$ adalah 0,15 . Hal ini menunjukkan $\mathrm{L}_{\text {hitung }}<\mathrm{L}_{\text {tabel }}$, artinya sampel berasal dari populasi yang berdistribusi normal.

Sedangkan uji normalitas nilai postes untuk kelas yang menggunakan buku teks diperoleh nilai $\mathrm{L}_{\text {hitung }}=0,145, \mathrm{~L}_{\text {tabel }}$ pada taraf $\alpha=0,05$ dengan $\mathrm{n}=35$, adalah 0,15 . Hal ini menunjukkan $\mathrm{L}_{\text {hitung }}<\mathrm{L}_{\text {tabel }}$, artinya sampel berasal dari populasi yang berdistribusi normal.

Berdasarkan uji normalitas kedua kelas diatas, maka dapat disimpulkan bahwa seluruh populasi data penelitian berdistribusi normal.

\section{Uji Homogenitas Data}

Untuk menguji homogenitas pretes dilakukan dengan menggunakan rumus uji fisher. Dari hasil perhitungan diperoleh nilai varians pretes untuk kelas yang menggunakan model pembelajaran penguatan vocational life skills berwawasan kewirausahaan dengan pe- rangkat modul adalah 12,72 dan varians pada kelas yang menggunakan buku teks adalah 10,78. $F_{\text {hitung }}=1,179$ Harga $F_{\text {tabel }}$ dengan taraf $\alpha=0,05$ dan $\mathrm{n}=35$ dengan dk pembilang 34 dan dk penyebut 2 adalah 3,28 , maka $\mathrm{F}_{\text {hitung }}<$ $\mathrm{F}_{\text {tabel }}$ yaitu $1,179<3,28$ dan kesimpulan data menyatakan bahwa postes kedua sampel untuk kelas yang menggunakan modul vocational life skills berwawasan kewirausahaan dan kelas yang menggunakan buku teks mempunyai varians yang sama atau homogen.

Untuk menguji homogenitas postes juga dilakukan dengan menggunakan rumus uji fisher. Dari hasil perhitungan diperoleh nilai varians postes untuk kelas yang menggunakan modul vocational life skills berwawasan kewirausahaan pembelajaran adalah 5,65 dan varians pada kelas yang menggunakan buku teks adalah 3,883 . $\mathrm{F}_{\text {hitung }}=1,45$. Harga $\mathrm{F}_{\text {tabel }}$ dengan taraf $\alpha=0,05$ dan $\mathrm{n}=35$ dengan $\mathrm{dk}$ pembilang $34 \mathrm{dan} \mathrm{dk}$ penyebut 2 adalah 3,28 , maka $F_{\text {hitung }}<F_{\text {tabel }}$ yaitu 1,45 $<3,28$ dan kesimpulan data menyatakan bahwa postes kedua sampel untuk kelas uji coba dan kelas normal mempunyai varians yang sama atau homogen.

\section{Uji Hipotesis}

Hipotesis yang diajukan dalam penelitian ini adalah (1) model pembelajaran penguatan vocational life skills berwawasan kewirausahaan layak digunakan dalam pembelajaran di bidang teknik mesin, dan (2) model pembelajaran penguatan vocational life skills berwawasan kewirausahaan efektif digunakan dalam pembelajaran di bidang teknik mesin. Namun untuk menilai kelayakan model pembelajaran yang dikembangkan beserta perangkatnya berupa modul pembelajaran di bidang teknik mesin bewawasan kewirausahaan dilakukan pada seluruh mahasiswa yang mengambil matakuliah Teknologi Pemesinan, Teknologi Pembentukan, dan Teknologi Pengelasan. Sedangkan untuk mengetahui keefektifan model pembelajaran penguatan vocational life skills berwawasan kewirausahaan dengan mengetahui hasil belajar mahasiswa 
yang diajar dengan menggunakan model yang dikembangkan beserta modul dan yang diajar dengan menggunakan pembelajaran eksositori dengan buku teks. Untuk menguji hal ini digunakan uji-t.

Nilai rata-rata hasil belajar dengan menggunakan modul vocational life skills berwawasan kewirausahaan dilakukan dengan perhitungan:

$$
\begin{aligned}
& X_{1}=\frac{\text { Jumlah skor yang diperoleh }}{\text { Jumlah skor total }} \\
& X_{1}=\frac{3112}{3500}=88,91
\end{aligned}
$$

Sedangkan nilai rata-rata hasil belajar dengan menggunakan buku teks diperoleh:

$$
\begin{aligned}
& X_{1}=\frac{\text { Jumlah skor yang diperoleh }}{\text { Jumlah skor total }} \\
& X_{1}=\frac{2871}{3500}=82,03
\end{aligned}
$$

Untuk Efektivitas penggunaan modul pembelajaran penguatan vocational life skills berwawasan kewirausahaan dilakukan dengan perhitungan:

$$
\begin{aligned}
& X_{1}=\frac{\text { Jumlah skor } \text { yang diperoleh }}{\text { Jumlah skor total }} \\
& X_{1}=\frac{3112}{3500}=88,91
\end{aligned}
$$

Keefektifan pembelajaran dengan menggunakan buku teks diperoleh dengan cara perhitungan sebagai berikut:

$$
\begin{aligned}
& X_{1}=\frac{\text { Jumlah skor } \text { yang diperoleh }}{\text { Jumlah skor total }} \\
& X_{1}=\frac{2871}{3500}=82,03
\end{aligned}
$$

Nilai efektivitas penggunaan media pembelajaran dengan modul yang diberi penguatan vocational life skills berwawasan kewirausahaan dibandingkan dengan penggunaan buku teks adalah:

$88,91-82,03=6,88$

$6,88 / 82,03 \times 100 \%=8,38 \%$

Dari hasil perhitungan efektivitas di atas, dapat disimpulkan bahwa nilai rata-rata hasil belajar yang diajar dengan menggunakan model pembelajaran penguatan vocational life skills berwawasan kewirausahaan dengan perangkat modul sebesar 88,91, sedangkan nilai rata-rata hasil belajar yang diajar dengan menggunakan buku teks sebesar 82,03. Untuk Persentase Efektivitas hasil belajar siswa yang diajar dengan menggunakan model pembelajaran penguatan vocational life skills berwawasan kewirausahaan dengan perangkat mo$\operatorname{dul} X_{I}=88,91 \%$ lebih tinggi dari hasil belajar siswa yang diajar dengan menggunakan buku teks yaitu $X_{2}=82,03 \%$.

Nilai efektivitas penggunaan model pembelajaran penguatan vocational life skills berwawasan kewirausahaan dengan perangkat modul bila dibandingkan dengan konvensional dengan menggunakan buku teks adalah sebesar $8,38 \%$. Sedangkan dari hasil pengolahan data diperoleh $t_{\text {hitung }}$ sebesar 11,80 , sedangkan $t_{\text {tabel }}$ pada taraf $\alpha=0,05$ dengan dk 68 adalah 1,67 , maka $t_{\text {hitung }}>t_{\text {tabel }} ;(11,80>1,67)$. Hasil yang diperoleh dikatakan signifikan (hipotesis diterima) jika harga $t_{\text {hitung }}>t_{\text {tabel }}$ untuk taraf signifikasi 0,05. Berdasarkan hasil data maka dapat disimpulkan bahwa terdapat perbedaan hasil belajar pada siswa yang diajar dengan model pembelajaran penguatan vocational life skills berwawasan kewirausahaan dengan perangkat modul dibandingkan dengan hasil belajar pada siswa yang diajar secara konvensional dengan menggunakan buku teks pada taraf signifikan 0,05 (5\%).

\section{Pembahasan}

Pengembangan model pembelajaran penguatan vocational life skills berwawasan kewirausahaan pada matakuliah kewirausahaan terutama pada kompetensi pengelolaan usaha dan kepemimpinan adalah pengembangan bahan pembelajaran dengan menggunakan model pembelajaran penguatan vocational life skills berwawasan kewirausahaan dengan perangkat pembelajaran yang menyertainya, berupa modul, strategi pembelajaran, metode pembelajaran, sebagai bentuk presentasi (penyajian) dengan memperhatikan aspek pembelajaran dan media sebagai prinsip desain pesan pembelajaran yang kolaboratif dan konstruktif mengacu pada konstrukstifisme dalam pembelajaran. Sejalan dalam penelitian dan pengembangan yang dilakukan oleh Sugiyanto, Slamet, \& Sugiyono (2016, p. 302) menyatakan bahwa model pembelajaran memiliki keunggulan harus ada: (1) perencanaan yang sistematis terhadap pengembangan kompetensi secara berkelanjutan, (2) pengkoordinasian yang sistematis di dalam pengembangan kompetensi secara berkelanjutan, (3) adanya petunjuk pelaksanaan yang rinci, (4) pengendalian terhadap pelaksanaan model, dan (5) evaluasi yang operasional. Terkait terhadap hasil penelitian dan pengembangan Murtini (2016) menyatakan bahwa vocational life skill berwawasan kewirausahaan harus 
dimulai melalui tahapan: (1) grup (kelompok) kecil, (2) eksplorasi ,(3) pengembangan ide usaha, (4) penyusunan dan presentasi rencana usaha, (5) aksi dan kompetisi usaha.

Peneliti dan pengembangan model pembelajaran penguatan vocational life skills berwawasan kewirausahaan diantaranya juga mengembangkan modul vocational life skills berwawasan kewirausahaan untuk menghasilkan media yang padat materi, mudah dipahami, mudah digunakan, dan tidak membosankan serta menarik bagi mahasiswa karena dilengkapi dengan gambar, foto, animasi serta video pembelajaran yang dapat memperjelas tujuan pembelajaran yaitu pada kawasan kognitif, afektif dan psikomorik. Hal ini sejalan dengan penelitian Anggraini \& Sukardi (2016, pp. 24-30) menyimpulkan bahwa penggunaan modul perlu digunakan untuk mempermudah mahasiswa dalam proses pembelajaran, menjaga motivasi, perhatian serta melayani kebutuhan belajar secara mandiri ataupun berkelompok dapat mengatasi keterbatasan waktu, ruang, menarik, meningkatkan kemampuan, dan dapat meningkatkan kemandirian dalam belajar. Demikian juga dengan penelitian yang dilakukan oleh Pebruanti \& Munadi (2015, p. 365) bahwa penggunaan modul dapat: (1) meningkatkan motivasi belajar. (2) meningkatkan hasil belajar (nilai sikap, nilai pengetahuan dan praktik), sehingga dapat memberikan ketuntasan klasikan $85 \%$ dari total siswa, yaitu: pada nilai pengetahuan dan praktikum sebesar $88,24 \%$, serta nilai sikap sebesar $91,18 \%$.

Bersumber dari hasil tiga tahap evaluasi terhadap produk yang dikembangkan, dapat diketahui bahwa kualitas media pembelajaran yang dikembangkan mempunyai kualitas sangat baik, hal ini dapat di lihat dari validasi oleh ahli media dan ahli materi maupun ujicoba perorangan, kelompok sedang dan uji coba lapangan yang dilakukan pada siswa sebagai pengguna produk. Ahli materi memberikan skor 87,69 dengan kriteria sangat baik, ahli desain pembelajaran memberikan skor 93,61dengan kriteria sangat baik, dan ahli media memberikan skor 77,10 dengan kriteria baik, siswa responden pada uji perorangan memberikan skor 92,82 pada uji kelompok kecil dengan skor 92,61 dan uji lapangan dengan skor 93,02. Dan skor ratarata secara keseluruhan adalah 89,48 dengan criteria sangat baik.
Uji coba produk juga menunjukkan hasil yang positif dengan adanya peningkatan yang signifikan pada hasil belajar siswa yang ditunjukkan dengan uji $\mathrm{t}$, dengan $\mathrm{t}_{\text {hitung }}$ sebesar 11,80 dengan $t_{\text {tabel }}$ sebesar 1,67 pada taraf signifikan $0,05(5 \%)$. Hal ini berarti penggunaan modul vocational life skills berwawasan kewirausahaan dapat menjadi efektif digunakan dalam pembelajaran. Kenyataan ini sesuai dengan pernyataan Richey \& Klein (2007, p. 11) konsep pengembangan model pembelajaran, konsep model yang dikembangkan, dan rancangan model lebih ditekankan pada desain dan pengembangan penelitian itu sendiri. Sehingga dalam desain sistem pembelajaran, model biasanya menggambarkan langkah-langkah atau prosedur yang perlu ditempuh untuk menciptakan aktivitas pembelajaran yang efektif, efisien, dan menarik (Pribadi, 2010 , p. 86). Jadi suatu model dalam pengembangan pembelajaran adalah suatu proses yang sistematik dalam desain, konstruksi, pemanfaatan, pengelolaan, dan evaluasi sistem pembelajaran. Hal ini sesuai terhadap model yang dikembangkan dalam penelitian dan pengembangan ini.

Efektivitas dapat ditinjau dari dua segi, yaitu guru mengajar dan siswa belajar yang belajar: Efektivitas mengajar menyangkut sejauh mana kegiatan pembelajaran yang direncanakan terlaksana. Sedangkan efektivitas belajar sejauh mana tujuan pelajaran dirumuskan dapat tercapai. Berdasarkan pernyataan tersebut dari hasil penelitian dinyatakan bahwa dengan nilai rata-rata hasil belajar sebesar 88,91 kriteria sudah tercapai. Dengan melihat pedoman dan kriteria penilaian, dari data hasil keefektifan modul, maka dapat disimpulkan bahwa penggunaan modul vocational life skills berwawasan kewirausahaan terbukti "sangat efektif" dalam meningkatkan hasil belajar, serta peningkatan kompetensi dan pengetahuan mahasiswa pada mata kuliah kewirausahaan dan sudah memenuhi kategori sangat baik dan layak serta efektif digunakan dalam pembelajaran. Adanya tahap revisi memberikan kualitas media pembelajaran yang dikembangkan menjadi semakin baik ditinjau dari aspek materi, aspek desain, dan aspek media. Pada saat proses validasi produk siswa tidak merasa kesulitan menjalankan program, bahkan mereka termotivasi untuk mempejari pesan yang ada di dalamnya dan lebih mudah memahami konsep 
yang diberikan dibanding tanpa menggunakannya dalam proses belajar.

Produk modul vocational life skills berwawasan kewirausahaan yang dikembangkan secara berurutan. Materi berurutan artinya materi pertama dipelajari terlebih dahulu kemudian materi kedua dan seterusnya. Modul pembelajaran yang dikembangkan ini mencakup: (1) materi sesuai dengan kemampuan mahasiswa dan disusun secara menarik untuk mencapai kompetensi yang diharapkan, (2) dirancang secara sistematis dan dikemas dalam satu modul secara utuh (self contain$e d)$,(3) dapat digunakan untuk belajar mandiri (self instructional), dan penggunaannya tidak tergantung media lain (self alone) (4) dapat digunakan untuk latihan dan mengukur kemampuan dengan melakukan tes sendiri (self test), (5) mengakomodasi kesulitan belajar dan memberi kesempatan mengembangkan diri mahasiswa dengan materi pengayaan, (6) mempunyai asesories sampul yang lengkap atau minimal memiliki topik yang jelas, (7) mempunyai rumusan kompetensi dasar atau kemampuan akhir, (8) mempunyai uraian dan contoh yang disusun secara sistematis, rinci dan lengkap, (9) mempunyai latihan soal atau tes formatif untuk melakukan tes sendiri, dan (10) mempunyai daftar pustaka yang mutakhir dan jumlahnya memadai.

Namun demikian dibalik kelebihan ada keterbatasan yang tidak dapat dihindari dalam pengembangan model dan modul pembelajaran vocational life skills berwawasan kewirausahaan. Berdasarkan komentar validator (ahli materi, desain dan ahli media) serta mahasiswa sebagai pengguna di setiap akhir uji produk dapat disimpulkan bahwa dengan menggunakan model pembelajaran penguatan vocational life skills berwawasan kewirausahaan yang dikembangkan untuk untuk mahasiswa menjadi lebih termotivasi dan diberi kemudahan dalam belajar, pengetahuan yang abstrak dapat dikonkritkan. Mahasiswa juga berpendapat bahwa dengan adanya modul yang dikembangkan mampu mempermudah pemahaman konsep kewirausahaan dan dapat diimplementasikan.

\section{SIMPULAN}

Model pembelajaran vocational life skills berwawasan kewirausahaan dalam pelaksanaannya secara konseptual mendasarkan kepada beberapa pendekatan pembelajaran, berkaitan langsung dengan strategi pembelajaran vokasional life skill berwawasan kewirausahaan di bidang teknik mesin yang dikembangkan adalah layak dan efektif digunakan dalam pembelajaran di bidang teknik mesin. Berdasarkan penelitian pendahuluan pada studi lapangan melalui survei dijelaskan bahwa dikembangkan model pembelajaran dan strategi pembelajaran disamping bahan pembelajaran berupa buku ajar yang berbasis vokasional life skill berwawasan kewirausahaan. Untuk mengetahui bagaimana pelaksanaan model pembelajaran yang dikembangkan proses pembelajaran dapat berlangsung sesuai, kondisi kelas, pengelolaan kelas, dan pengukuran kriteria untuk tugas-tugas belajar keterampilan kewirausahaan dan bidang keahlian terhadap kompetensi mata kuliah yang diambil pada teknolodi pengelasan, teknologi pembentukan dan teknologi pemesinan.

Strategi pembelajaran sangat penting untuk membantu dosen dan mahasiswa dalam mengkreasi, menata, dan mengorganisasi pembelajaran sehingga memungkinkan peristiwa belajar terjadi dalam rangka mencapai tujuan belajar. Model pembelajaran penguatan vocational life skills berwawasan kewirausahaan sangat diperlukan untuk memandu proses belajar secara efektif yang memiliki landasan teoretik yang humanistik, lentur, adaptif, berorientasi kekinian, memiliki sintak pembelajaran yang sedehana, mudah dilakukan, dapat mencapai tujuan dan hasil belajar yang disasar. Model pembelajaran penguatan vocational life skills berwawasan kewirausahaan yang dapat diterapkan pada bidang studi hendaknya dikemas koheren dengan hakikat pendidikan bidang studi tersebut. Secara filosofis tujuan pembelajaran adalah untuk memfasilitasi mahasiswa dalam penumbuhan dan pengembangan kesadaran belajar, sehingga mapu melakukan olah pikir, rasa, dan raga dalam memecahkan masalah kehidupan di dunia nyata. Model pembelajaran penguatan vocational life skills berwawasan kewirausahaan dapat mengakomodasikan tujuan tersebut berlandaskan pada paradigma konstruktivistik sebagai paradigma alternatif berlandaskan paradigma konstruktivistik yang sesuai dengan hakikat pembelajaran humanis populis.

Model pembelajaran penguatan vocational life skills berwawasan kewirausahaan melalui pemberian serangkaian pengetahuan dan pelatihan kewirausahaan berpengaruh 
positif terhadap meningkatnya spirit kewirausahaan dan meningkatnya kemampuan/keterampilan yang telah dilakukan dalam rangka usaha, diperkuat dengan dukungan dan pembinaan pihak-pihak yang terkait, adanya pendampingan berkelanjutan, dan pembinaan untuk pengembangan jaringan usaha, khususnya untuk memasarkan hasil usaha secara efektif.

\section{DAFTAR PUSTAKA}

Alma, B. (2002). Kewirausahaan. Bandung: Alfabeta.

Anggraini, F., \& Sukardi. (2016). Pengembangan modul pembelajaran kewirausahaan model student company di smk negeri 1 Godean. Jurnal Pendidikan Vokasi, 6(1). Retrieved from http://journal.uny.ac.id/index.php/jpv/art icle/view/8113

Anwar. (2004). Pendidikan kecakapan hidup (life skills education) konsep dan aplikasi. Bandung: Alfabeta.

Badan Pusat Statistik. (2016). Berita Resmi Statistik. BPS Provinsi Sumatea Utara. No. 65/11/12/Th. XIX, 7 November.

Borg, W. R., \& Gall, M. D. (1989). Educational research: an introduction (4th ed.). New York: Longman.

Dick, W., \& Carey, L. (1985). The systematic design of instruction. Glenview, Ill: Scott, Foresman.

Dick, W., \& Carey, L. (1996). The systematic design of instruction. New York, NY: HarperCollins College Publishers.

Dick, W., Carey, L., \& Carey, J. O. (2005). The systematic design of instruction (6th ed.). Boston: Pearson/Allyn and Bacon.

Gunter, M. A., Estes, T. H., \& Schwab, J. H. (1990). Instruction: a models approach. Boston: Allyn \& Bacon.

Joyce, B., \& Weil, M. (2000). Model of teaching. Amerika: A. Pearson Education Company.

Joyce, B., Weil, M., \& Beverly, S. (1996). Models of teaching. Boston: Allyn \& Bacon.

Kementerian Pendidikan Nasional. (2002). Pedoman pelaksanaan program keterampilan hidup (life skills) oleh perguruan tinggi. Jakarta: Direktorat
Pendidikan Masyarakat. Direktorat Jenderal Pendidikan Luar Sekolah.

Kuratko, D. F., \& Hodgetts, R. M. (2007). Entrepreneurship: theory, process, practice (7th ed.). Canada: Interactive Composition Corporation.

Mager, R. F., \& Beach, J. K. (1967). Developing vocational instruction. Callifornia: Pearson Pitman.

Miarso, Y. (2005). Menyemai benih teknologi pendidikan. Jakarta: Kencana.

Murtini, W. (2016). Implementasi model "gepprak" dalam pembelajaran kewirausahaan untuk meningkatkan minat berwirausaha di sekolah menengah kejuruan. Jurnal Pendidikan Vokasi, 6(3). Retrieved from http://journal.uny.ac.id/index.php/jpv/art icle/view/11176

Nasution, A. H., \& Suef, M. (2007). Entrepreneurship, membangun spirit teknopreneurship. Yogyakarta: Andi Offset.

Pebruanti, L., \& Munadi, S. (2015). Peningkatan motivasi dan hasil belajar pada mata pelajaran pemograman dasar menggunakan modul di SMKN 2 Sumbawa. Jurnal Pendidikan Vokasi, 5(3). Retrieved from http://journal.uny.ac.id/index.php/jpv/art icle/view/6490

Potter, J. (2008). Entrepreneurship and higher education (OECD). Paris.

Pribadi, B. A. (2010). Model desain sistem pembelajaran. Jakarta: Dian Rakyat.

Richey, R. ., \& Klein, J. . (2007). Design and development research. New Jersey: Lawrence Erlbaum Associates.

Seels, B. B., \& Richey, R. C. (1994). Instructional technology: the definition and domains of the field. Washington, DC: AECT.

Sugiyanto, Slamet, \& Sugiyono. (2016). Pengembangan kompetensi profesional berkelanjutan dosen vokasi pada pendidikan vokasional di lampung. Jurnal Pendidikan Vokasi, 6(3). Retrieved from http://journal.uny.ac.id/index.php/jpv/art icle/view/10967 